\title{
PRIMARY SCHOOL TEACHERS' WELFARE: A PREREQUISITE FOR QUALITATIVE PRIMARY EDUCATION IN NIGERIA
}

\section{SHEHU UTHMAN EL-YAKUB (PhD)}

\begin{abstract}
Education is the most important vehicle for progress and overall development of individual in particular and society in general. Yearning for positive development and progress cannot come by without sound primary education background, teacher is the prime mover of education in general without whom, education can hardly be acquired. No education system can rise above the quality of its teachers, this gives important support for teacher on their role in the first place, as educators, implementers of the curriculum content and determinant factors that influence the needed learning outcomes of instruction. Primary school teachers in Nigeria suffer serious neglect in terms of their social welfare especially in the areas of salaries and allowances, in-service training, office accommodation as well as inadequate funding of primary education. The paper also brought the issues on child's needs for education, universal basic education and suggestions were proffered.
\end{abstract}

\section{Introduction}

Primary education, according to the National Policy on Education (NPE, 2013) refers to the education given to children aged 6 to 12 years. It also referred this level of education so important that, it is the key to the success or failure of the whole system.

Primary education is given consideration in the National Policy on Education which categorically states its goals among other things to:

a. inculcate permanent literacy and numeracy;

b. lay sound foundation for scientific and reflective thinking;

c. $\quad$ citizenship education for effective participation in the society;

d. mould character for sound attitude and morals; and

e. develop in the child ability to adapt to the societal or environmental change (NOPE, 2013: 22).

Nwalado \& Nwalado (2007) cited the objectives of Universal Primary Education UBE in Nigeria as follows:

1. developing in the entire citizenry a strong consciousness of education and a strong commitment to its vigorous promotion;

2. provision of free, universal basic education for every Nigerian child of school-going age;

3. reducing drastically the incidence of drop-out from formal school system;

4. catering for the learning needs of young persons who, for one reason or another have had to interrupt their schooling through appropriate forms of complementary approaches to the provision and promotion of basic education; and

5. ensuring the acquisition of appropriate levels of literacy, numeracy, manipulative, communicative and life skills as well as ethical, moral and civic values needed to lay a solid foundation for life long learning. 


\section{The Child's needs for Education}

Universal Basic Education (UBE) is a branch of Education for All (EFA) which is a global movement led by UNESCO with the aim of meeting the learning needs of children, youth and adults by the year 2015 .

In the year 2000, the international community met a Dakar, Senegal, the event recorded 1100 participants, it was gathered from the reports of the participants that many countries could not achieve the goals of the (EFA) and the participants agreed on the Dakar Framework for Action which re-affirmed their commitment to achieving Education for All by the year 2015 (UNESCO, 2010).

EFA identified six key measurable educational goals which aim to meet the learning needs of all children by the year 2015. The EFA's goals are collective commitments of the international community as said by UNESCO (2010), the aims of which to;
a. $\quad$ expand early childhood care and education;
b. $\quad$ provide free and compulsory primary education for all (UBE);
c. promote learning and life skills for young people and adults;
d. increase adult literacy by 50 percent;
e. $\quad$ achieve gender parity by 2005 , gender equality by 2015 ; and
f. improve the quality of education.

The same goals were set to be achieved by the Nigerian UBE in order to satisfy the needs of the Nigerian children. The fundamental question here is, has the targeted 2015 been achieved?

Primary education in Nigeria according to the National Policy (2013: 18) is tuition free, universal and compulsory. The subjects taught in primary schools include:

\section{Primary Classes $1-3$}

1. English Studies

2. One Nigerian Language

3. Mathematics

4. Basic Science and Technology

$>\quad$ Basic Science

$>\quad$ Basic Technology

$>\quad$ Information Technology

$>\quad$ Physical and Health Education

5. Religion and National Values

$>\quad$ Christian Religious Studies

$>\quad$ Islamic Studies - Social Studies 
$>\quad$ Civic Education

$>\quad$ Security Education

6. Pre-Vocational Studies

$>$ Home - Economics

$>\quad$ agriculture

7. Cultural and Creative Arts

8. Arabic (Optional)

\section{Primary 4-6}

1. English Studies

2. One Nigerian Language

3. Mathematics

4. Basic Science and Technology

$>\quad$ Basic Science

$>\quad$ Basic Technology

$>\quad$ Information Technology

$>\quad$ Physical nd Health Education

5. Religion and National Values

$>\quad$ Christian Religious Studies

$>\quad$ Islamic Studies

$>\quad$ Social Studies

$>\quad$ Civic Education

$>\quad$ Security Education

6. Pre-Vocational Studies

$$
\begin{array}{ll}
> & \text { Home }- \text { Economics } \\
& \text { agriculture }
\end{array}
$$

7. French Language

8. Cultural and Creative Arts

9. Arabic (Optional)

In many primary schools in Nigeria, teachers are involved in teaching all subjects in their allocated classes. Although the National Policy on Education (2013: 24) stipulated that specialist teachers of particular subjects should be provided, but insufficient number of teachers in many primary schools in Nigeria could not allow that to be put into practice. 
School libraries, basic health schemes, counselling units and educational resource centres were also not available in most of the public primary schools in Nigeria as included or required in the National Policy. If the provision of these laudable ideas and the items were made available, primary education in Nigeria would have been better than whatr it is presently. The provision of these facilities would go a long way to enhance quality of instruction and teachers would be motivated more to put in their best in their day-to-day teaching activities, (El-Yakub, 2012).

\section{The Primary School Teacher's Role in Curriculum Implementation}

Agaokogbuo (2000: 118), views that the inclusion of the teacher as a factor in curriculum activities stems from the fact that he assumes an enviable position in implementing the curriculum. Teacher is consider important because, he determines the interpretation of the curriculum and thereby determines the learning outcomes of instruction.

Teacher, at every stage or class stimulates learning and presents facts to guide the pupils and learning activities, teachers at primary level and other levels of learning have knowledge of characteristics of the learners, their needs, interests and learning problems which enable the teachers to prepare suitable, relevant and appropriate learning programmes for the learners at an appropriate time within an academic year or term. Teacher gives orientation to the learner about his society and its future development, teachers the child value, culture, tradition and the aspirations of the society. Positive orientation of the younger generation of the society solely depends on the teacher, however, this aspect of the teacher's role is emphasised during pre-service training as a counsellor (Adebayo, 1998).

Role of the teacher in curriculum cannot be overemphasised when it comes to determine the courses or subjects to be taught to pupils and even suggests the textbooks to be used. If the teacher's role is deemphasised in curriculum planning and implementation such curriculum becomes very difficult and children may also have difficulty in comprehending the instruction. Teacher when involved in curriculum planning can use his experience to suggest materials. Teacher when involved in curriculum planning can use his experience to suggest materials, resources which are available locally and their substitutes that both urban and rural school pupils can understand as a result of involving a teacher.

Balogun et al., (1981: 90) observe that in Nigeria, primary school teacher plays a passive role in determining the process of curriculum. The curriculum is already planned by officials of Ministry of Education (MOE) and National Education Research Development Council (NERDC) because of this, the teacher interprets the curriculum anyhow, teaches what he knows and overlooks the rest. Consequently, the teacher cannot adequately use suggested materials in the curriculum, and when not available will not be able to improvise.

Non-involvement of primary school teacher in curriculum planning, apart from making him a passive participant may also being number of implementation problems which may result to poor educational background for Nigerian children right from primary education level as well as failure in future public examinations. 
The curriculum planning bodies have a huge responsibility to carry out in an attempt to involve primary school teacher in curriculum planning for example, the problem of quantity, and quality of these teachers should be addressed with the view to improving it. Teachers of primary schools, apart from not being involved in curriculum planning, are not adequately remunerated which make them to seek other ways for making money to meet their daily needs instead of concentrating on their primary assignments (Balogun, et al., 1981).

Involving the teacher in curriculum planning means, boosting his teaching morale and urging him to work better. There is urgent need for the teacher to take new roles, advising, helping, encouraging independent and self judgment, questioning and exploring. It is teacher's role to make his teaching appropriate, interesting and to become acceptable to the learner. This can effectively be achieved when the primary school teacher's role is no longer seen to be of a mere implementer of a planned or prepared curriculum but as a participant in the process of curriculum building (Asiedu-Akrofi, 1981: 17).

\section{Primary School Teachers Welfare}

Welfare, according to Mairi \& George (2004), us referred to as the health, comfort, happiness and general well-being of a person or group etc. Teachers in Nigerian, in most case are blamed for poor performance of pupils and students at the final examinations, but the socioeconomic needs of these teachers are not adequately catered for in both public and private school sector in Nigeria.

Teachers in Nigeria encounter series of problems including lack of job satisfaction, irregular salaries and allowances payment, low status in the society. Teachers' morale is low because there is nothing to boost their morale as basic teaching aids are in state of decay (Nwalaldo \& Nwalado, 2007).

Nwalado \& Nwalado (2007) also listed problems of teachers welfare which exist to date among others include the following:

1. Irregular payments of teachers

2. Inadequate funding of primary education

3. Lack of in-service training

4. Inadequate and poor infrastructural facilities

5. Poor office accommodation

6. Poor instructional facilities/resources

7. Irregular promotion etc.

The above problems are not only problems bedevilling primary education sector, teachers are still facing a number of challenges and threats to their profession in Nigeria. For example, numbers of them were killed by Boko Haram insurgents in their attempt to discourage western education in the North - East Zone. Numbers of primary schools in the zone were closed down especially those in the rural areas. 
Teachers without pedagogical competencies cannot assist teaching and learning in primary schools, if such is practiced, affects not only primary school sector but the entire education sector in the country as "No education system can rise above quality of its teachers".

Pupils population explosion is seen as one of the teachers' problems in Nigeria as the National Policy on Education (2013: 20 - 21), enshrined that, for effective teaching and learning, the teacher - pupil ratio shall be 1: 35 in primary, Creche 1: 10 and Kindergarten 1: 25. In some primary schools multiple numbers are found against the accepted ratio.

Information Communication Technology (ICT) facilities are yet to be introduced to number of public primary schools in Nigeria, some teachers of such schools are not aware of the advantages of ICT to their teaching and instructional activities, such teachers still find it difficult to effectively implement their lessons in the classroom. The (NPE, 2013: 27), recognises the importance of ICT in primary school, it states:

In recognition of prominent role of Information and Communication Technology in advancing knowledge and skills necessary for effective functioning in the modern world, there is urgent need to integrate Information Communication Technology (ICT) into education in Nigeria.

Afe (2006), lamented that, in spite of the immensity of the roles teachers play in the society there is abundant evidence to suggest that teachers have not been receiving sufficient attention in terms of their management and support. The issues of most concern to teachers morale and motivation, performance and productivity are in the areas of salaries and conditions of service which are neglected. Teachers in some states are promoted only on paper without financial backing or remunerations.

Teachers morale and motivation in the areas of teaching and teaching materials, conditions of service and staff development are among the critical issues affecting primary school teachers in Nigeria which in turn, have a negative effect(s) on their general performance in classroom.

\section{Conclusion}

Teachers in primary schools in Nigeria play an indispensable role in the education sector, pupils look upon them to learn, society depend on them to realise its dream regarding progress and educational development in the society. The National Policy on Education reaffirmed that the rest of the education system is built upon the primary education; it is also the key to the success or failure of the whole system.

Teacher on the other hand is in a dilemma, welfare problems are so many that his morale and motivation to work is not encouraging which affect his productivity in his primary assignments. Such problems includes conditions of service as a national issue, in school, no teaching - learning materials, staff development opportunities and poor salaries and allowances are among serious problems of the Nigerian teachers. 
There is abundant evidence to suggest that unless teachers are cared and catered for, curriculum planning and effective delivery cannot be recorded. The need to make improvement in the areas salaries and allowances, staff development, teaching and instructional materials and general conditions of service are paramount.

\section{Recommendations}

Teachers as in the frontline of curriculum delivery in schools, there is a dare need to look at them with view to making improvement from the present situation which they are not happy with. This paper recommends that:

1. Teachers morale and motivation be increased in order to encourage them to stay on the job. This can be done in many ways like, increase in salaries and allowances; teaching - learning materials be made available and so on.

2. Training and retraining of teachers can be encouraged in order to update their knowledge and certificates to teach as qualified teachers for the benefits of pupils in particular and society in general.

3. Teaching learning environment should be made conducive, neat classrooms, teachers offices and the school be equipped with modern teaching - learning resources like computers and so on.

4. Teachers promotion from one grade to another should be done accordingly and with financial backing.

5. Government should consider paying research allowance to primary school teachers who must be made to show evidence of use of such funds for research purposes (Nwalado \& Nwalado, 2007).

\section{References}

Adebayo, O. A. (1998). Vision and Mission of Pre-Primary and Primary Education in Nigeria, A National Commission for Colleges of Education, Kaduna: Nigeria.

Aguokogbuo, C. N. (2000). Curriculum and Implementation for Africa. Mike Social Press, 4 University Road, Nsukka.

Afem, J. O. (2006). Reflections on Becoming a Teacher and the Challenges of Teacher Education. Inaugural Lecture Series 64, Faculty of Education, University of Benin, Benin City, Nigeria.

Asiedu - Akrofi, K. (1981). The Living Classroom. George Allen \& Unwin, London.

Balogun, D. A.; Okon, S.; Musaazi, E. and Thakur, A. S. (1981). Principles and Practice of Education. Macmillan Publishers Ltd. Ibadan: Nigeria.

El-Yakub, (2012). Unpublished Lecture Notes, Primary School Teachers Welfare in Kaduna State PDE Class, Institute of Education, ABU, Zaria. 
Federal Republic of Nigeria (2013). National Policy on Education. NERDC Press, Yaba: Lagos, Nigeria.

Mairi, R. and George, D. (2004). Chambers, $21^{\text {st }}$ Century Dictionary. Chambers Publishers Ltd. 7 Hopetoun Crescent, Edinburgh, EH 7 4AY.

Nwalado, S. H. and Nwalado, E. N. (2007). Journal of Childhood and Primary Education (1), Publication of the Nigerian Primary and Teacher Education Association, NERDC, Abuja.

UNESCO (2010). “Education Counts”, http://www.un.org/en/globalissues/briefingpapers/efa 